\title{
Dominant Types of Errors at Parallel Kinematics Machine Tools
}

Zoran Pandilov

Full Professor

University "Sv. Kiril i Metodij"-Skopje Faculty of Mechanical Engineering Republic of Macedonia
Theoretically, parallel kinematics machine tools should be very accurate and rigid due to their closed loop structure and no error accumulation characteristics. Unfortunately, these theoretical presumptions have not been confirmed in practice, due to manufacturing and assembly errors, kinematic errors in the actuators and joints, elastic deformations due to the gravity, thermal deformations, limited sensor accuracy, control errors, etc. This paper gives a survey of the types of errors which significantly decrease the expected accuracy of the parallel kinematics machine tools.

Keywords: parallel kinematics, machine tools, dominant errors, accuracy

\section{INTRODUCTION}

Parallel kinematics machine tools have attracted the attention of research institutions and industry due to their high theoretical structural rigidity and high accuracy due to the closed kinematic loops and no error accumulating characteristics.

The first prototypes of parallel kinematics machine tools were introduced in public in 1994 by Ingersoll and Ginddings and Lewis (Fig.1 and Fig 2).

Although more than 20 have years passed since the first commercial parallel kinematics machine tools were introduced, they are not widely accepted in the industry. In that period more that 50 different parallel kinematics machine tools structures were realised, but only few had commercial success.

From the beginning of their appearance it has become obvious that implementation of their theoretical capabilities in practice introduces many new problems. Accuracy of the parallel kinematics machine tools has become one of their main weaknesses.

But, what is the difference between theory and practice?

For the parallel kinematics machine tools control and theoretical investigations generally a simplified model based on several assumptions is used. The assumptions are [1]:

-each joint has one centre point for all rotational degrees of freedom,

-these centres are precisely known,

-the linear actuators move with only one degree of freedom and pass exactly through the joint centres,

-the leg length can be read without errors, and -no internal and external loads affect the manipulator.

But these assumptions will easily fail for a real machine tool due to manufacturing and assembly errors, kinematic errors in the actuators and joints, elastic deformations due to the gravity, thermal

Received: March 2016, Accepted: February 2017

Correspondence to: Prof. Dr. Zoran Pandilov

University "Sv. Kiril i Metodij"-Skopje, Faculty of

Mechanical Engineering, Republic of Macedonia

E-mail: panzo@mf.edu.mk

doi:10.5937/fmet1704491P

(C) Faculty of Mechanical Engineering, Belgrade. All rights reserved deformations, limited sensor accuracy, control errors, etc.

In this paper several most dominant errors which have the greatest influence on the parallel kinematics machine tools accuracy will be presented.

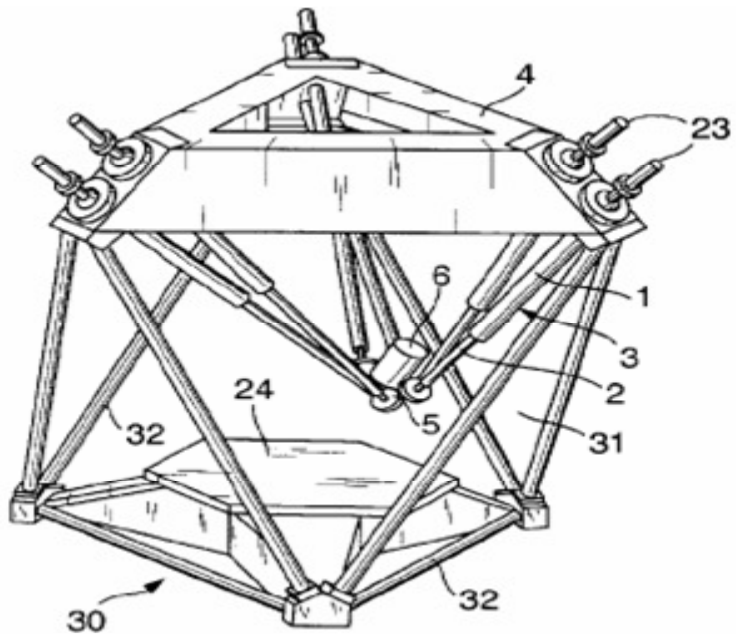

a)

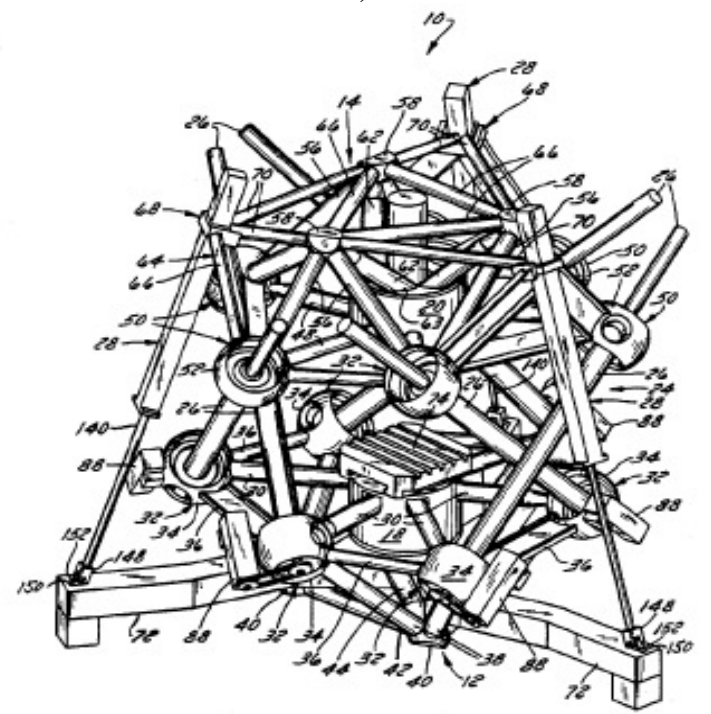

b)

Figure 1. Schemes of parallel kinematics machine tools a) Ingersoll's "Octahedral Hexapod b) Giddings \& Lewis' "Variax" 


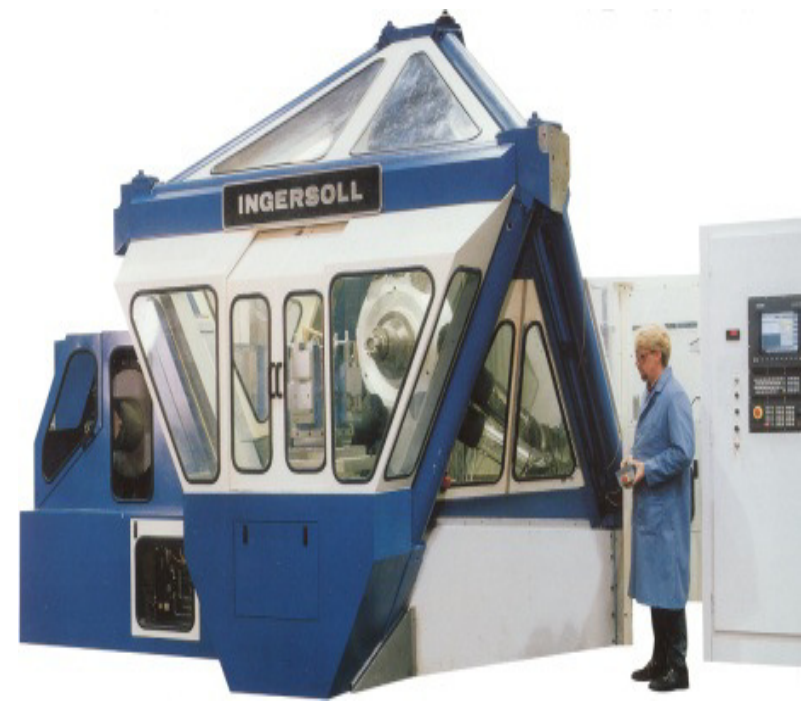

a)

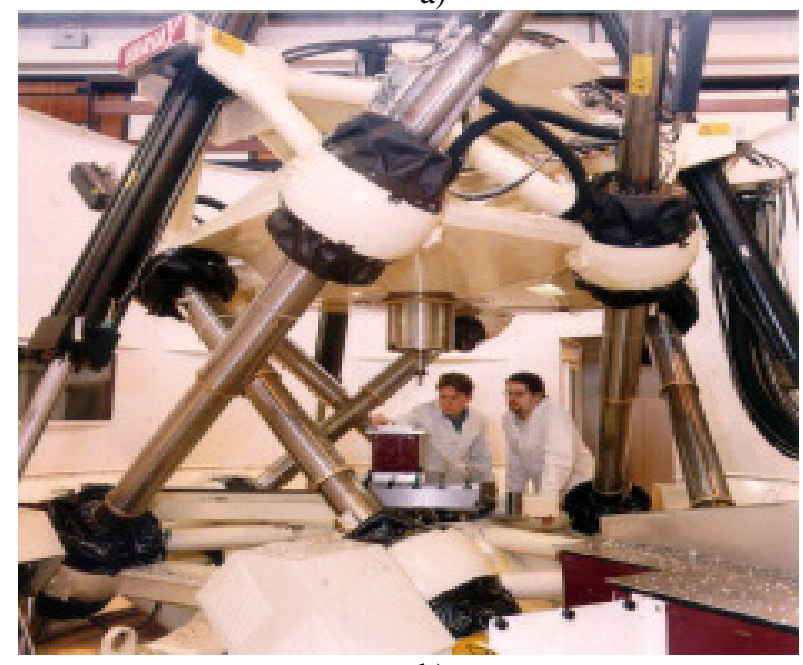

b)

Figure 2. Photos of the first parallel kinematics machine tools a) Ingersoll's "Octahedral Hexapod" b) Giddings \& Lewis "Variax"

\section{TYPES OF ERRORS}

On the parallel kinematics machine tools accuracy, various types of errors have great influence. Because the occurring errors are partially dependent on the dynamics and process forces during the machining, the difference between static and dynamic errors should be made [2].

Static errors are errors not dependent on the dynamics and process forces, whereas the source of dynamic errors is in the machining method.

\subsection{Static and quasi-static errors}

When the accuracy of any machine tool is specified, usually only the static accuracy is considered. This does not provide reliable information about what will be the machine tool accuracy during the machining process. A high static accuracy is a basic requirement for machine tool operation, especially in the finishing operations and positioning processes. In the following, several static errors will be described.

\section{Kinematic and transformation errors}

Manufacturing and assembly errors of the joints and actuators introduce kinematic errors. Only errors in the local direction of leg are important [3]. Straightness and angular errors of the actuator as well as an offset of the leg in a joint orthogonal to the strut direction could be neglected as second order elements.

However, straightness and angular errors of the leg become very important if they introduce errors in integrated metrology systems, caused by Abbey's effect, especially under bending load caused by the weight of the actuator itself. This effect can be drastically reduced by a proper design and placement of the sensor system.

Transformation errors occur by deviations of the kinematic model within the control and real machine tool kinematics. There are two reasons for transformation errors. The first is simplification of the kinematic model and the second is the fact that the model parameters are not known exactly.

Typical simplifications of the kinematic model are for example, the neglected offsets between the axes of cardan joints and the unevenness of linear axes. If these refinements are considered, the effort for calculating the transformation becomes significantly higher. So they can not be calculated any more in presently available controls.

The geometric parameters used in the transformation are identified by calibration. The main difference between the calibration of parallel kinematic machines and the calibration of serial kinematic machines lies in the very high number of geometric parameters at parallel kinematic machines. The method for calibration of parallel kinematic machines consists of measurement the position and orientation of the tool centre point at several points in the workspace. Afterwards, the geometric parameters of the kinematics are determined by a numerical optimization.

The accuracy achieved with this optimization depends on various factors. Measuring method used for determining the position of tool centre point during the calibration plays an important role. Because of nonlinear coupling of all parameters a one-dimensional measurement as, for example, $x$ component of the tool position or the distance between tool tip and fixed point, could be enough. But if we know the positions and orientations of the tool centre point in the measuring points, a higher accuracy will be achieved by calibration.

Another important factor is the number of measuring points and requirement for the measuring points to be spread over the whole workspace. The more measuring points are used, the real geometric parameters can be better determined by averaging.

Maximum magnitude of the kinematic and transformation errors could reach 0.1-0.5 mm [4].

\section{Gravitational errors}

The weight of the tool platform leads to elastic deformations of the real machine tool structure due to the flexibility of machine kinematics and machine components. 
For example, there are several highly compliant joints, such as universal and ball-joints, ball-screw, nut and supporting bearings, in the driving mechanism (Fig.3).

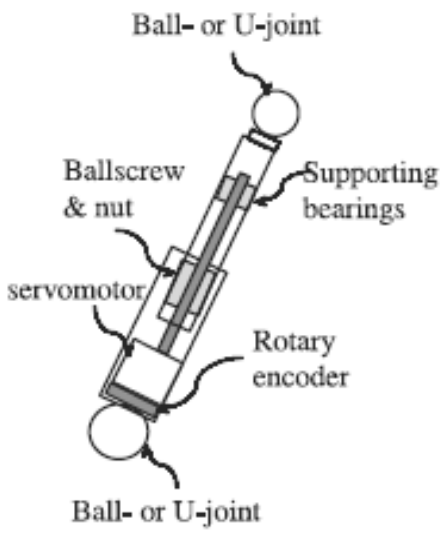

Figure 3. Example of one leg of a hexapod based parallel kinematic machine tool [5]

At the serial kinematics machine tools deformation caused by gravity is approximately constant in the entire workspace and therefore is the best automatically to be considered already with calibration. But gravitation forces in parallel kinematics machine tools have very significant effect due to the non-constant stiffness in the workspace.

This error could reach maximum values up to $0.5-1$ $\mathrm{mm}$ [4]. Typical values are about $0.2 \mathrm{~mm}$ [6].

One possibility to reduce the gravitation errors is compensation in numerical control unit based on elastic model. Application of even very simple models leads to very good results. Usually it is enough to make calculation with non complex lumped masses for the tool platform and for the actuators. But elastic models need the exact stiffness of the kinematic components. Therefore the stiffness of the struts should be measured before assembling the machine.

\section{Thermal errors}

Thermal errors are another important source that significantly decrease the accuracy of the parallel kinematics machine tools. Thermal deformations happen with a high time constant and result in slowly changing of quasi-static errors.

There are different sources of thermal drift under working conditions. The major error source is the thermal expansion of the legs due to the heat generated in ball screw drives [7]. These errors can be drastically reduced if thermal invariant direct measurement systems are used.

Another important source is the drift of joints due to the thermal expansion of the moving platform and the base frame caused by internal or external thermal loads (Fig. 4).

The platform is mainly thermally loaded by the heat of cutting process and heat generated of spindle bearings. The frame is mainly influenced by changes in the ambient temperature and this could be source of great errors. The heat generated by the actuators due to power loss influence on the rise of the temperature in the legs and the frame of parallel kinematics machine tool.

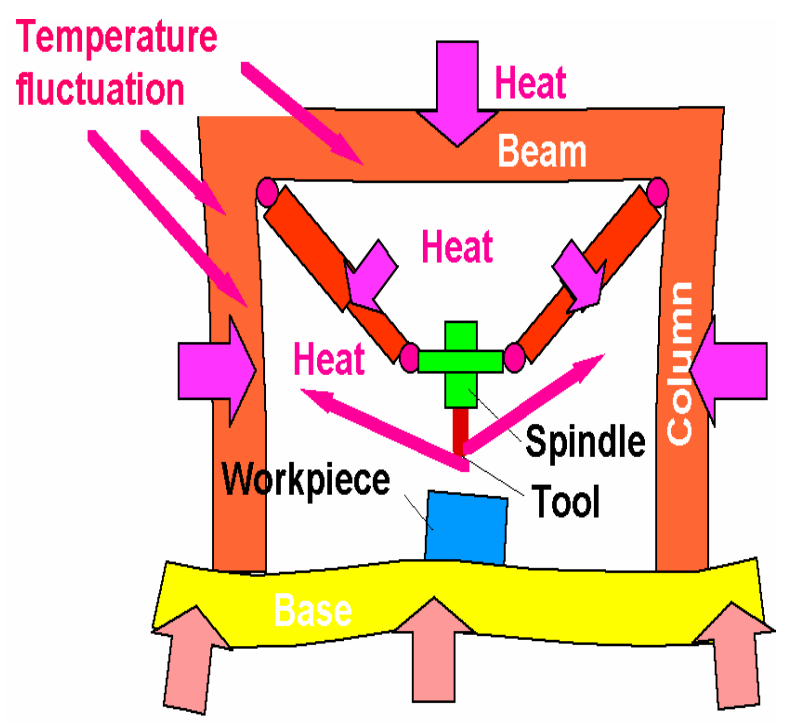

Figure 4. Thermal expansion of the moving platform and the base frame [8]

The most effective measure against thermal errors is the cooling of thermally affecting kinematics components.

Another possibility to reduce the errors caused by thermal deformations is temperature measurement of the components and compensation of the resulting deformation using a thermal model. Because of the limited accuracy and complexity of the thermal model for the parallel kinematics machine tools, and high number of needed temperature sensors, this procedure is restricted regarding the achievable machine accuracy [9].

Thermal errors could reach values up to $0.5 \mathrm{~mm}$.

\subsection{Dynamic errors}

When we have machining at low speed and low process forces, the static and quasi-static errors determine the machine accuracy. An example is smoothing process which is normally driven at a very low feed rate and requires high accuracy. But smoothing is only possible if the contour of the work piece is very close to the final contour. In order to achieve this, the preceding machining phases should have been executed accurately to a certain degree.

Especially at high-speed machining with parallel kinematics machine tools, the dynamic errors have a much stronger impact than the static errors. The reason for dynamic errors are drive errors, e.g. tracking error and coupled oscillations, elastic deformations of the machine kinematics structure from the process forces or inertial forces and natural vibrations of the machine. Whether there is an effect and how strong the impact of these error sources will be, depends on the process forces, acceleration and velocity. High process forces are the cause of drive errors due to a low disturbance (dynamic) stiffness of the drives. A low stiffness of the machine kinematics results in big errors when the process forces and dynamics (speed and acceleration) are high. Lower stiffness of the machine kinematics 
enables bigger errors which are the result of deformations from the process and inertial forces.

Other dynamic errors, like the errors caused by natural vibrations, cannot be directly attributed to the machining force or acceleration, even they only occur during the process.

\section{Errors from elastic deformations}

Elastic deformation errors result from the limited stiffness of the machine tool, when it is loaded with the force. Besides the already mentioned static gravitation errors, also the machining force and the inertial forces caused by acceleration motion, lead to deformations that result in considerable errors. The stiffening of the machine kinematics, very often could be impossible, due to the limits of the required lightweight construction. An estimation of the occurring errors by calculation of the stiffness, the process forces and inertial forces in real-time, can only be achieved using highly simplified models. Usually, this is not a very successful method.

Errors from elastic deformations could reach the values of up to $0.1 \mathrm{~mm} \mathrm{[2].}$

\section{Errors from natural vibrations}

Errors from natural vibrations are often based on the stiffness of the machine kinematics. The natural vibration with the lowest frequency plays the most important role, since, it is the upper limit for the dynamics of a machine tool. It is extremely difficult to eliminate the natural vibrations, using the elastic model in the numerical control.

These errors could reach values up to $0.05 \mathrm{~mm}$.

\section{Drive errors}

An important requirement for high-speed machining with parallel kinematic machine tools are highly dynamic drives which enable low level contouring errors at high speed and acceleration. Drives also have to deal with the load dependent operating point and with the coupling of the drives, which can in some cases excite each other and start to oscillate [10].

Typical drive errors are the width of backlash when the velocity inverses the direction, the velocity proportional contouring error depending on the control parameters and deviations due to the disturbance forces. Linear direct drives disturbance (dynamic) stiffness depends primarily on the control parameters of the drive controller. For ball screw drives, the mechanical stiffness of the drive, also plays an important role.

Drive errors could be reduced or eliminated, only by implementation of improvements in the drive control.

Typical values of drives errors could be up to 0.01 $\mathrm{mm}$.

\section{CONCLUSION}

In this paper, different types of errors which significantly decrease the parallel kinematics machine tools accuracy are given. Static errors are caused by manu- facturing and assembly errors, inaccurate transformation and by deformations of the machine kinematic structure through weight forces. Quasi-static errors are the result of thermal deformation of machine tool. Dynamic errors occur only during the manufacturing processes and depend on the velocity, acceleration and process forces. Dynamics errors are deformations caused by inertia and process forces, natural oscillations and drive errors.

\section{ACKNOWLEDGMENT}

This research was done at the Department of Machine Tools and Automation, TU Hamburg-Harburg, Germany, financed by DFG (Deutsche Forschungsgemeinschaft).

\section{REFERENCES}

[1] Weck M., Staimer D.: On the Accuracy of Parallel Machine Tools: Design, Compensation and Calibration, 2nd Chemnitz Parallel Kinematics Seminar, PKS 2000, Chemnitz, 2000, pp.73-83.

[2] Pritschow G., Eppler C., Garber T.: Influence of the Dynamic Stiffness on the Accuracy of PKM, $3^{\text {rd }}$ Chemnitz Parallel Kinematics Seminar, PKS 2002, Chemnitz, 2002, pp.313-333

[3] Soons J. A.: On the Geometric and Termal Errors of a Hexapod Machine Tools, Proccedings of the First European-American Forum on Parallel Kinematic Machines, 31.08.-01.09.1998, Milano, Itally, pp.151-170.

[4] Eastwood S., Webb P.: Error Mapping, Modelling and Compensation for Hybrid Parallel Kinematic Machines, 4th Chemnitz Parallel Kinematics Seminar, PKS 2004, Chemnitz, 2004, pp. 653-667.

[5] Hsu W.-Y., Chen J.-S.: Error analysis and autocalibration for a Cartesian-guided tripod machine tool, Int. J. Adv. Manuf. Technol. (2004) 24: pp. 899-909.

[6] Ibaraki S. et al.: Compensation of Gravity-Induced Errors on a Hexapod-Type Parallel Kinematic Machine Tool, JSME International Journal Series C, Vol. 47 (2004), No. 1 Special Issue on Advanced Manufacturing Technology, pp.160-167.

[7] Heisel U., Precision requirements of HexapodMachines and Investigation Results, Proccedings of the First European-American Forum on Parallel Kinematic Machines, 31.08.-01.09.1998, Milano, Itally, pp.131-150.

[8] Oiwa T.: Study on Accuracy Improvement of Parallel Kinematic Machine (Compensation Methods for Thermal Expansion of Link and Machine Frame), Proceedings of the 1st Korea-Japan Conference on Positioning Technology (CPT2002), 2002, pp.1-6

[9] Kruth J.-P., Vanherck P., Van Den Bergh C.: Compensation of Static and Transient Thermal Errors on CMMs, Annals of CIRP, 50/1/2001, pp.377-384.

[10] Pritschow G., Eppler C., Lehner W. -D.: Ferraris Sensor-The Key for Advanced Dynamic Drives, Annals of the CIRP Vol. 52/1/2003, pp.289-292. 


\section{ДОМИНАНТНИ ТИПОВИ ГРЕШАКА КОД МАШИНА АЛАТКИ СА ПАРАЛЕЛНОМ КИНЕМАТИКОМ}

\section{3. Пандилов}

Теоретски гледано машине алатке са паралелном кинематиком требало би да буду прецизне и круте јер представљају затворени систем и нема нагомилавања грешака. Нажалост, теоријске претпоставке нису потврђене у пракси због грешака које настају у производњи и монтажи, грешака у кинематици актуатора и спојева, еластичних деформација изазваних гравитацијом, топлотних деформација, ограничене прецизности сензора, грешака у управљању, итд. Рад даје преглед типова грешака које значајно смањују очекивану прецизност машина алатки са паралелном кинематиком. 